\title{
Notes on the vocalizations of Drab Whistler (Pachycephala griseonota)
}

\section{Peter Boesman}

In the following we briefly analyze and compare voice of the different races of Drab Whistler (Pachycephala griseonota). We also try to quantify the extent of any vocal differences using the criteria proposed by Tobias et al. (2010), as a support for taxonomic review. We have made use of sound recordings available on-line from Xeno Canto (XC), Macaulay Library (ML) and Avian Vocalizations Center (AVoCet).

The distinctiveness of race johni was discussed in Thibault et al. (2013), including a limited comparison of voice. This was however based on a single recording made in 2010. Since, four more recordings have become available (John Mittermeier, $\mathrm{ML}$ ), illustrating a far more extensive vocabulary then previously suggested (Fig. 1).

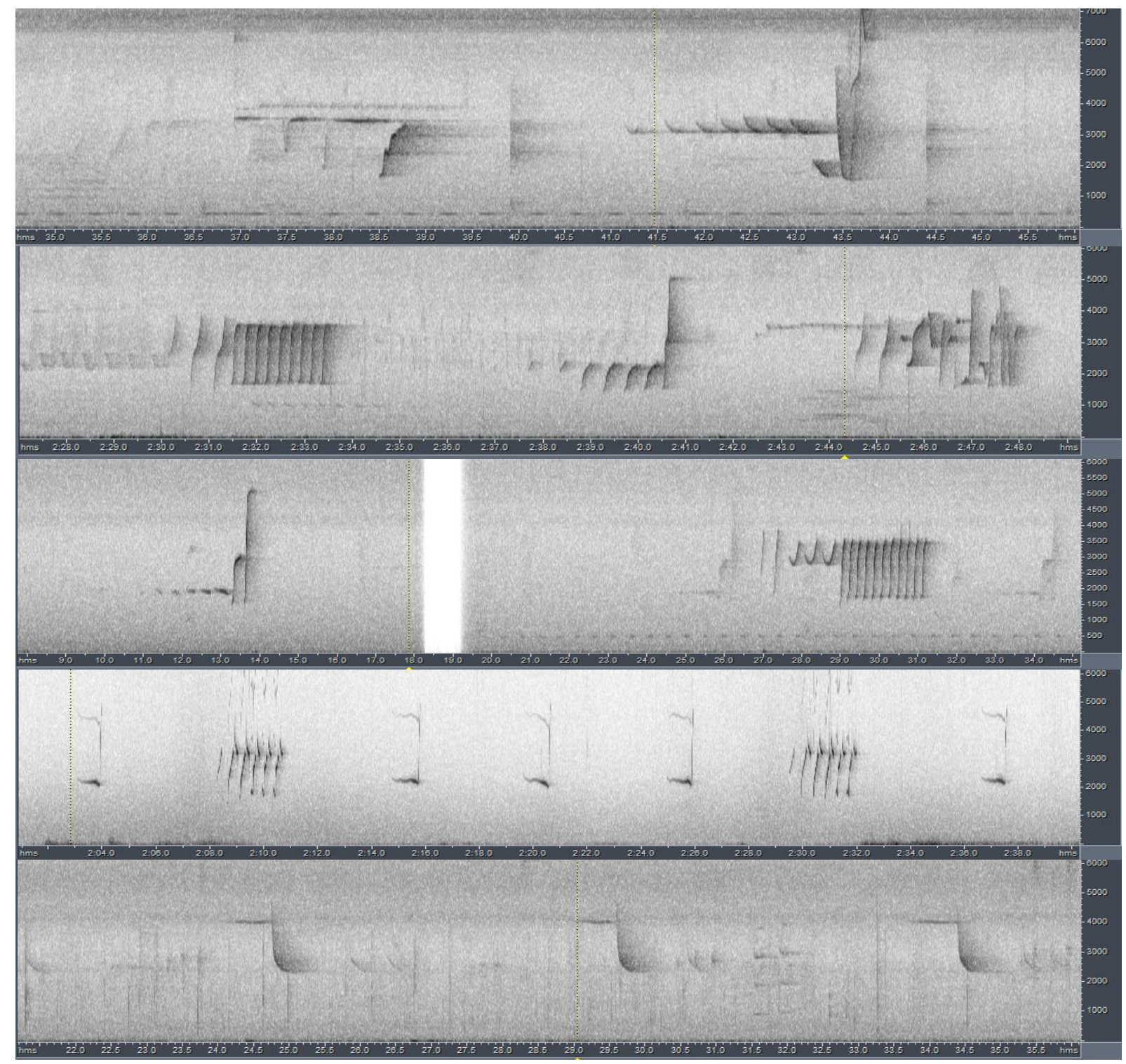

Figure 1: vocalisations of race johni (not all sonograms have same time scale !) 

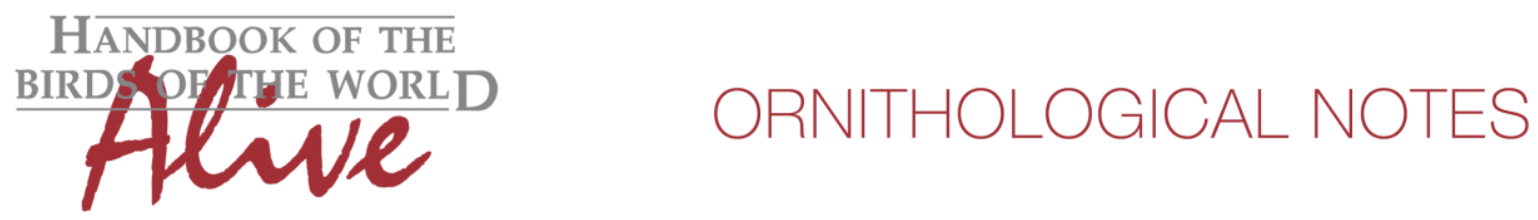

Many of these phrases are (very) similar to song phrases from other races (Fig. 2), despite the fact that there are (also) only a handful of recordings available for other races.

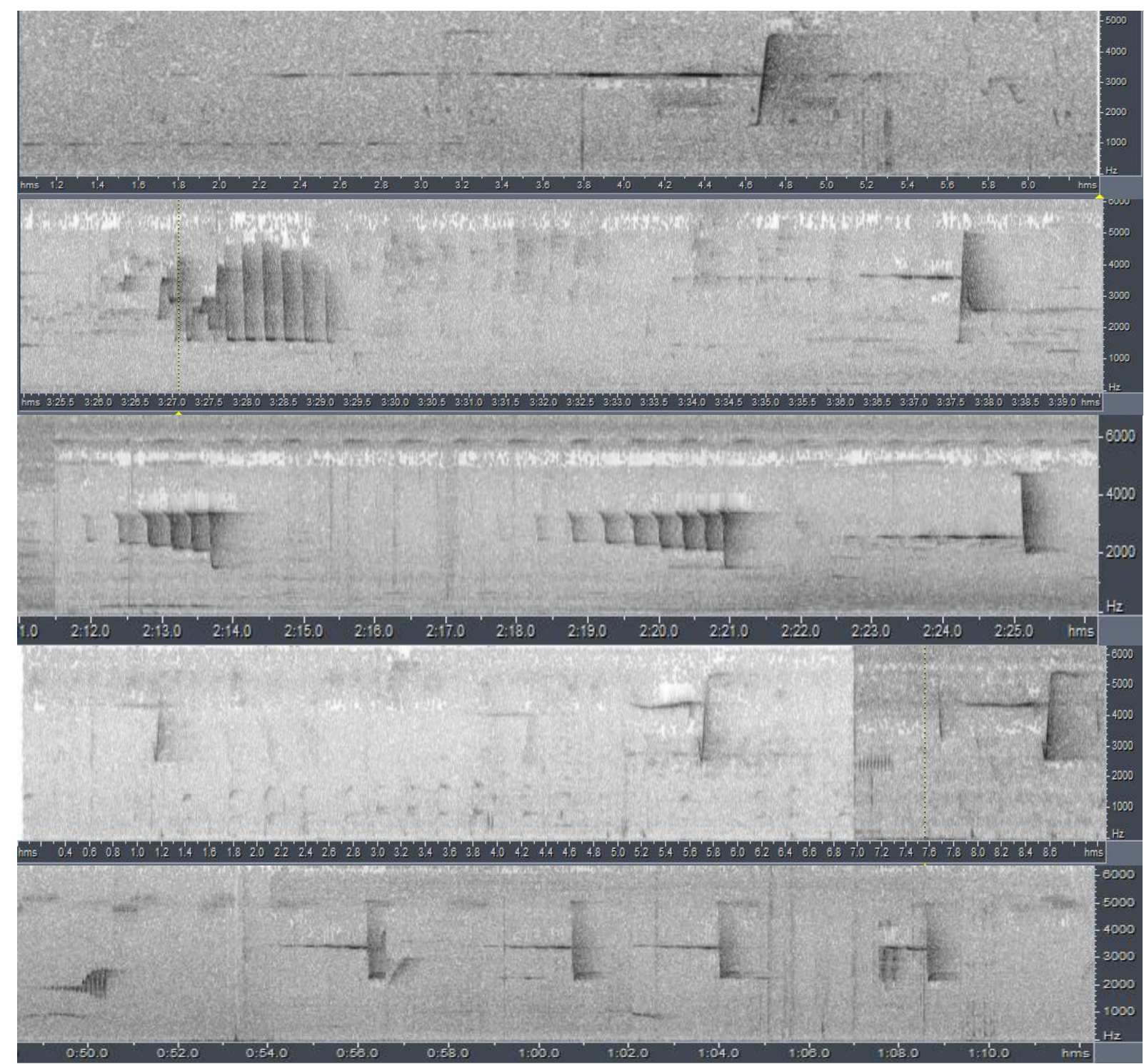

Figure 2: some examples of vocalisations of $P$. griseonota similar to examples shown for race johni

There may be phrases that are unique for certain races, but in general it would seem that due to the extent of variation, basic sound parameters are very much the same:

$\begin{array}{llll} & \text { Thibault rec. } & \text { ML recordings } & \text { other races } \\ \text { Duration song phrase } & 0.5-2 \mathrm{~s} & 1-4 \mathrm{~s} & 0.7-3.9 \mathrm{~s} \\ \text { \# of notes in song phrase } & 3-10 & 1-15 & 1-10 \\ \text { min./max. freq. } & 1.7 / 5.5 \mathrm{kHz} & 1.5 / 5.5 \mathrm{kHz} & 1.5 / 5.5 \mathrm{kHz}\end{array}$

This being said, I have not found a good match in other races for the johni phrase which was depicted in Thibault et al. and which also can be found at the end of second sonogram in Fig. 1: a series of all different whistles sounding more warbling than other phrases. 

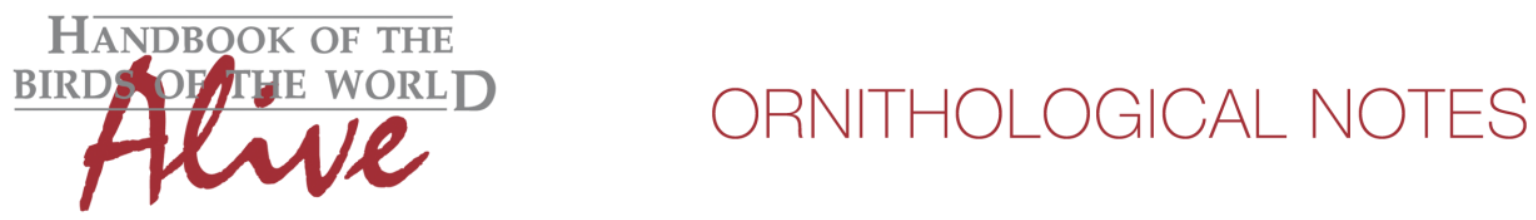

It is possible that this and other phrases are truly unique for johni, but given the limited number of recordings available, the extent of vocal variation and the fairly large number of races (six), it seems premature to conclude that johni is vocally distinct from all other races as a group. Even then, with all sound parameters basically overlapping, by applying Tobias criteria a score for vocal difference would remain low.

This note was finalized on 14th October 2015, using sound recordings available on-line at that moment. We would like to thank in particular the sound recordists who placed their recordings for this species on XC, ML and/or AVoCet: Bram De Meulemeester, Frank Lambert, John Mittermeier, Mike Nelson and George Wagner.

\section{References}

Thibault, M., Defos du Rau, P., Pineau, O. \& Pangimangen, W. (2013). New and interesting records for the Obi archipelago (north Maluku, Indonesia), including field observations and first description of the vocalisation of Moluccan Woodcock Scolopax rochussenii. Bull. Brit. Orn. Club 133(2): 83-115.

Tobias, J.A., Seddon, N., Spottiswoode, C.N., Pilgrim, J.D., Fishpool, L.D.C. \& Collar, N.J. (2010). Quantitative criteria for species delimitation. Ibis 152(4): 724-746.

\section{Recommended citation}

Boesman, P. (2016). Notes on the vocalizations of Drab Whistler (Pachycephala griseonota). HBW Alive Ornithological Note 162. In: Handbook of the Birds of the World Alive. Lynx Edicions, Barcelona. (retrieved from http://www.hbw.com/node/932092 on 18 August 2016). 